\title{
The Level of Education and Digital Political Culture: Facing the 2019 Election in Mengkudu Bay, North Sumatra
}

\author{
Erond L. Damanik \\ \{eronddamanik@yahoo.com\} \\ Department of Anthropology, Faculty of Social Sciences, Universitas Negeri Medan, Indonesia
}

\begin{abstract}
The level of education influences knowledge, attitudes and political evaluations in the face of the 2019 General Election. In the digital era, the General Election is a means of persuasively determining candidates through digital communication to shape political behavior, namely the orientation of a typical attitude towards candidates. This study aims to discuss and understand the level of education and the digital political culture in fishing communities facing the General Election in 2019. The fundamental problem of this study is formulated in the question: is it true that the level of education influences political culture in the digital era? The assumption of this study states that the level of education greatly contributes to the political culture in the digital era. Explaining this problem is used the theory of Almonds and Verbs. The subject of this study was fishing communities in the village of Sialang Buah, Mengkudu bay sub-district, Serdang Bedagei district, North Sumatra province. The research data was collected through questionnaires and in-depth interviews. The questionnaires were distributed to 50 families containing 7 dimensions of democratic values with 4 alternative choices. The answers were analyzed based on the Likert Scale. The findings of this study are that the level of education contributes to the low level of digital political culture and the digital political culture more determined by patrons through the closeness of religion. This novelty confirms the tendency of the parochial political culture of fishing communities in the digital era. Digital political culture facing the General Election in 2019 is still focused on the religious line, namely the voting behavior characterized by nationalist-religious.
\end{abstract}

Keywords: level of education, digital political culture, elections, parochial.

\section{Introduction}

Education contributes to the development of political substance. Education is the most significant means of creating political quality for the life of the state. Political quality is seen in political culture, namely awareness, and participation in every political activity. The relationship between education and politics is the creation of cognition, affection, and evaluation of political objects [1]. These three components form understanding, feelings and political decisions. Political attitude is positioned as a product of evaluation of political objects through processes of cognition, affection, and behavior. Therefore, political culture is a product of political objects based on rational-objective considerations. As an evaluation product, political attitudes are cognitive, affective and evaluative responses through 
observation of political objects. Through this process, three political cultures are formed: (i) parochial, (ii) subject, and (iii) participants. The most expected political culture is the participant culture, namely the existence of sufficient awareness and political participation.

Political culture is achieved through the process of education, especially formal education. However, informal education (e.g. political parties, social-political institutions) contributes to political socialization. Formal education creates rational-objective individuals so that political evaluations tend to be healthy and of good quality. The higher the level of education, the better the political culture, on the contrary, the lower the level of education, the worse the political culture. This statement is very relevant in explaining that Western society is characterized by rationality, namely, behavior based on consideration and conscious choice to achieve its objectives [2], [3]. However, is Weber's statement relevant to explain political behavior in Indonesia? The social reality of the Indonesian people is still low educated. Only 7.2 percent of the people have higher education, 22 percent have secondary education and the rest have basic education. This really shows that the average education of Indonesian people does not pass junior high school [4]. This reality has an impact on the quality and understanding of political culture in Indonesia. The characteristic of the Fourth Industrial Revolution (4.0) in the 21 st century is the birth of digital platforms. This platform influences the creation of digital culture. Digital platforms include social networks like Facebook, search engines like Google, and smartphones like the iPhone. This device is very crucial as a communication media in the digital era [5]. Digital platforms such as WhatsApp and Twitter are political communication media, namely political conversation and discussion [6]-[9]. In the political arena, digital political platforms are used to increase political participation [10]. Each member on digital political platforms is discussed, comment, forward or share it with others. The discussion material on these platforms tends to vary. Topics like the real topic, viral topics, hoaxes, hate speech, shitposting, and others are debated. Digital political platforms are used to legitimize or negate candidates, reject or accept campaign programs and political parties. On the one hand, discussion leads to character assassination and achievement negation [11]. On the other hand, the discussion leads to the legitimacy of candidates and their political activities. Digital political platforms expect a political culture directed at the grassroots. This political culture is a product of political digitalization such as the existence of Political Hashtag [12]-[14], or its use as political communication.

The function of digital political platforms has increased significantly in facing the election on April 17, 2019. The most important output of election is not the election with the most votes but the presence of checks and balance mechanisms [15]. The election in 2019 is the persuasion of determining the president and the legislature. Even though the election is still 7 months away, digital political platforms have been enlivened by political discussions that negate and legitimize one another. The digital political platforms are used by political actors, political parties, legislative candidates, religious figures, ethnic figures, and participants to reject or accept candidates. Political messages were published, liked, commented on, forward and became the subject of discussion by national, regional and grassroots politicians. News and information from national media, national politicians and national figures are debated to negate and legitimize one another. Television broadcasts present various topics that lead to the elections in 2019. The overall effort is part of the creation of digital political culture in the face of the election in 2019. This study aims to understand the level of education and digital political culture in facing the election in 2019 at Sialang Buah village, Mengkudu Bay subdistrict, Serdang Bedagai Regency, North Sumatra province. The people are ethnic Malays and work as fishermen. Life as a fisherman reflects the level of low education, communalistic character, and patron-client dependence. This society is very loyal to the ethnic and religious 
identity of Islam. Preliminary studies show that the average community has a television or smartphone. Both of these devices become the main source of news and information for the community. Digital applications in the form of social networks such as Facebook and WhatsApp are on their smartphones. Both of these digital applications are a source of information networking that is received every day. Information on social network media is a matter of discussion for fellow fishermen, family, and relatives or during moments of religious activity. In some places, there are stalls that provide newspapers. This print media became a communal political reference. Religious activities are inseparable from their weekly activities which appear to present political discussion.

In some locations there are legislative and executive candidate banners. Photographs on banners show relevance to religion and ethnicity. In some photos, the candidate appeared to be wearing a shirt (Gamis) and cap (Peci) but wearing a Red and White flag (Bendera Merah Putih). Preliminary identification shows that the election in 2019 was a busy topic to discuss. Political conversation and discussion lead to legislative and executive candidacy. The discussion leads to legitimizing and negating certain candidates or political parties. Based on the above phenomenon, this study intends to understand the educational linkages to the political culture of the digital era in fishing communities. Political culture is focused on three dimensions namely cognition, affection and evaluation of political objects. In this study, the level of education is assumed to influence political culture in the digital era. The influence is seen in the understanding of objects, acceptance and political decisions, especially the tendency of voting behavior in the elections in 2019. This political culture is classified as parochial, subject and participant. This study is an effort to examine political culture based on the three classifications referred to as using a positive paradigm.

\section{Method and Our Analytic Task}

This study refers [1] to explain political culture. Education is the basis for the formation of a political culture that contains 7 dimensions of democratic values, namely subject competence, political interest, interpersonal trust, achievement motivation, national pride, and confidence in social and political institutions [16]. The level of education affects the assessment of religious, ethnic, cultural, political and socio-economic practices so that it impacts on political culture. Education determines the political culture of women and men, parents and young people. Education contributes to political orientation and behavior. Therefore, the level of education has an impact on the degree of political culture, namely parochial, subject or participant. Data collection activities were carried out by distributing questionnaires and in-depth interviews with research subjects. The questionnaire was distributed to 50 households, namely 133 subjects registered as permanent voters (Daftar Pemilih Tetap) at the election in 2019. In-depth interviews were conducted on 5 selected subjects according to their functions, namely religious figures, ethnic figures, housewives, young men, and women. The questionnaire contains dimensions of democratic values used by the World Values Survey [17]. However, every aspect of this dimension is adapted to the contemporary Indonesian political situation. Each of these dimensions has universal democratic values. This dimension reflects modern morality and political ethics. The answers are scored based on the Likert scale. Analysis and discussion are carried out descriptively based on interviews and non-parametric calculations. This study uses a positive paradigm to understand the relevance of the level of education to the digital political culture facing the election in 2019. 


\section{Findings and Discussion}

Sialang Buah is the capital of the sub-district of Mengkudu Bay, Serdang Bedagei district, North Sumatra province. This area is bordered by the Malacca Strait. According to [18], Sialang Buah consists of 6 hamlets (Dusun), 668 families and a total population of 3,523 people. Because the area is bordered by the sea, the majority $(67 \%)$ of the population is fishermen. However, there are traders $(22 \%)$, laborers $(6 \%)$, government employees $(2 \%)$ and others $(3 \%)$. The demographic composition based on ethnic groups showed Malay dominance $(68 \%)$, Javanese $(19 \%)$, Toba $(5 \%)$, Karo $(2 \%)$, Simalungun and Chinese $(1 \%$ each) and others $(4 \%)$. When viewed from the aspect of religiosity, Islam is the dominant religion (92\%), Protestant (4\%), and others (4\%). Based on data [19], the total permanent voters in the election in 2019 at Sialang Buah are 2,664 people. This number consists of 1,329 men and 1,335 women.The research subjects were 50 Malay families consisting of 174 people. By this amount, there is 133 are registered as permanent voters in the election in 2019. This number is used as the subject of research. The total number (133 people) consisted of 57 people (42.8\%) men and $82(61.2 \%)$ women. This number consists of 33 beginner voters aged 17-21 years $(24.8 \%), 69$ are voters aged $22-50(51.8 \%)$, and 31 voters are above the age of $50(23 \%)$. The whole subject is religious and homogeneous, namely Islam and Malay. The entire subject is fishermen who work catching fish, tufts, and processing salted fish. When viewed from education, 133 subjects indicated the level of education as in table 1 below, namely:

Table 1. Level of Education

\begin{tabular}{lcc}
\hline \multicolumn{1}{c}{ Level of education } & \multicolumn{2}{c}{ Answers } \\
\cline { 2 - 3 } & amount & $\%$ \\
\hline Primary school/equivalent & 73 & 54,8 \\
Junior high school/equivalent & 47 & 35,3 \\
Senior High school/equivalent & 12 & 9,0 \\
Academy & 1 & 0,7 \\
Bachelor $\quad$ Total & - & - \\
& $\mathbf{1 3 3}$ & $\mathbf{1 0 0}$ \\
\hline
\end{tabular}

The data in table 1 above shows the majority of subjects were junior high school graduates $(90.1 \%)$. While college graduates (academies) are only 1 person $(0.75 \%)$. The educational indicators are very important in testing political quality. Therefore, the social facts about the level of education show the quality of the political culture in Sialang Buah. The entire family of subjects in this study had a television and a smartphone. In fact, 62.4\% of 133 subjects owned a smartphone. By this amount, there are 83 subjects who owned smartphones using the communication and social network applications shown in table 2 below.

Table 2. The application of social media on a smartphone

\begin{tabular}{ccc}
\hline Application form & \multicolumn{2}{c}{ Answers } \\
\cline { 2 - 3 } & amount & $\%$ \\
\hline Twitter & 14 & 16,8 \\
Facebook & 64 & 77,7 \\
WhatsApp & 64 & 77,7 \\
Google & 64 & 77,7 \\
Youtube & 64 & 77,7 \\
Online Media & 8 & 9,6 \\
Online Game & 57 & 68,6 \\
\hline
\end{tabular}


The data in table 2 above shows that the Facebook, WhatsApp, Google, Youtube applications $(77.7 \%$ each) and Online Games $(68 \%)$ are used by the subject. While the subjects who have online media applications are only $9.6 \%$. This digital device is most often used for social network purposes $(87 \%)$, communication $(100 \%)$, and entertainment in the form of online games $(62 \%)$ and Youtube $(59 \%)$. The subjects that access news content through online media are less than 10 percent. This reality shows that online media is not yet a reference and smartphone tends to be used as a social network, communication, and entertainment. The subject's experience shows his confidence in the truth of the news posted through social media. However, information through digital devices greatly affects users. This reality occurs because of the lack of the ability of the subject to distinguish correct information, hoaxes, shit posting, hate speech or other pseudo-news. The data above indicates that the level of education is not an obstacle for subjects following digital innovation. However, the functions and benefits of digital devices are only as communication devices, social networks, and entertainment. Subjects do not have information validation skills so they tend to be consumed without filters. In other words, digital devices are not utilized maximally and their usage is still limited to lifestyle or following the trend of communication tools. This fact occurs because the level of education of the subject is insufficient to utilize digital devices, especially studying information. The level of trust in information through media devices tends to vary. Table 3 below classifies the subject's trust in information reference sources, as follows below.

Table 3. The most trusted news and information tools

\begin{tabular}{cccccc}
\hline No & Media & \multicolumn{4}{c}{ Answers } \\
\cline { 3 - 6 } & & $\begin{array}{c}\text { Agree } \\
\text { completely }\end{array}$ & $\begin{array}{c}\text { Agree } \\
\text { Somewhat }\end{array}$ & $\begin{array}{c}\text { Agree nor } \\
\text { disagree }\end{array}$ & $\begin{array}{c}\text { Completely } \\
\text { Disagree }\end{array}$ \\
\hline 1 & Facebook & 72 & 19 & 24 & 18 \\
2 & Twitter & 77 & 24 & 26 & 6 \\
3 & WhatsApp & 81 & 14 & 18 & 20 \\
4 & Online Media & 51 & 12 & 68 & 2 \\
5 & In-print Media & 66 & 42 & 19 & 6 \\
6 & Television & 92 & 9 & 27 & 5 \\
\hline
\end{tabular}

The data in table 3 above shows that television devices are a reliable reference for information (69.1\%) compared to other media. Print media tends to be trustworthy (49.6\%) while online media is considered untrustworthy $(51.1 \%)$. This really shows that the subject is still characterized by traditional society, not critical or skeptical. In other words, the character of the community still characterizes 'Gaptek' or 'failed technology'. This description shows that the subject does not have the ability to search, divide and filter information for consumption of reliable information. Digital devices namely WhatsApp are considered as trusted information applications (60.9\%) compared to Twitter (57.8\%) and Facebook (54.1\%). However, information received by users is still sending, like, share and comment on social networks. Subjects of smartphone users claim that they often receive persuasion and negation information in the form of short messages and pictures. This information is related to the presidential or legislative candidates in 2019. The subject claimed that persuasion and negation made the subject more confused. Referring to the content that is read, both through smartphone media, print and television media information is obtained as shown in figure 1 below. 


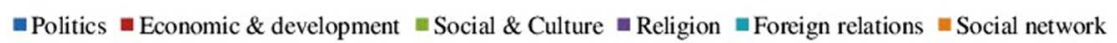

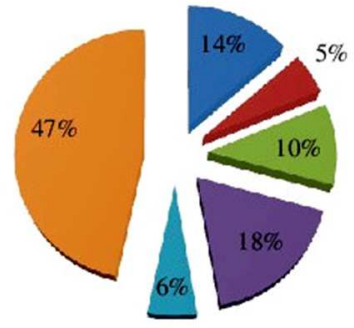

Fig. 1. The most frequently read content

The data in figure 1 above shows that digital devices are used for social networks (47\%) and access to religious content (18\%). Politically flavored content is only accessed $14 \%$ of the subject and foreign relations are accessed $6 \%$ which is quite limited to the Middle East. This data indicates that media devices, television, print, and digital are still limited in use. Even if used, then the content that is read is still focused on social and religious networks. This fact confirms the characteristics of a typical Malay ethnic who claims to be a communal and religious society.

The data above explains the characteristics of Malay education and society, namely (i) the level of education is very low, that is, the average graduate of elementary school, (ii) television and print media become trusted media of information and news compared to online media or social media, ( iii) the use of digital devices is still limited to entertainment or following the trend of communication modes, (vi) the most frequently accessed content is social network and religion, (v) typical of traditional communities that prioritize communalism, and (vi) religion as a total surrender to life's difficulties faced. Therefore, this low level of education not only has an impact on the low utilization of digital devices but also on the low political understanding. The following below describes the dimensions of democratic values in the form of Achievement Motivation of Malay people according to the World Values Survey. Based on the questionnaire distributed to 133 subjects found an overview of achievement motivation as in table 4 below, namely.

Table 4. Achievement Motivation

\begin{tabular}{cccc}
\hline No & Important values & \multicolumn{2}{c}{ Answers } \\
\cline { 3 - 4 } & & amount & $\%$ \\
\hline 1 & Good manners & 19 & 75,9 \\
2 & Independence & 13 & 50,3 \\
3 & Hard work & 7 & 33,0 \\
4 & Responsibility & 8 & 31,5 \\
5 & Imagination & 4 & 30,0 \\
6 & Tolerance & 9 & 27,8 \\
7 & Saving money & 4 & 32,3 \\
8 & Perseverance & 11 & 33,8 \\
9 & Religious faith & 31 & 81,2 \\
10 & Unselfishness & 25 & 78,1 \\
& N & $\mathbf{1 3 3}$ & $\mathbf{1 0 0}$ \\
\hline
\end{tabular}


The explanation of Table 4 above illustrates that the most important component of achievement of motivation is religious obedience $(81.2 \%)$, unselfishness $(78.1 \%)$, and politeness $(75.9 \%)$. This situation refers to the desire for achievement tends to be seen as a relationship with God and others. Individuals who are considered achievers are someone who shows religious obedience, such as diligent worship, Haji, Umroh or helping the poor (Sedekah). The actions of achievement are still very low, such as hard work (33\%), imagination $(30 \%)$, saving $(32.3 \%)$ and responsibility $(31.5 \%)$. This indication shows that the main priority of his life is primary needs and has not thought of secondary needs especially tertiary. This fact is caused by the low education factor and limited socio-economic conditions. The value of religious observance above has an impact on ethnocentrism. When the questionnaire contains the dimensions of democratic values in the form of most desirable neighbors, answers are obtained as shown in table 5 below.

Table 5. The most desirable neighbor

\begin{tabular}{ccccc}
\hline \multirow{2}{*}{ No } & & Ethnocentrism & \multicolumn{2}{c}{ Answers } \\
\cline { 3 - 5 } & & & amount & $\%$ \\
\hline 1 & Religion & Moslem & 128 & 96,2 \\
& & Catholic & 2 & 1,5 \\
& & Protestant & 1 & 1,1 \\
& & Buddhist & 1 & 1,1 \\
& & Kong Hu Chu & 1 & 1,1 \\
& \multirow{4}{*}{ Ethnic } & Karo & 2 & 1,5 \\
& & Simalungun & 1 & 1,1 \\
& & Mandailing & 8 & 6,0 \\
& & China & 3 & 2,2 \\
& & Melayu & 91 & 68,4 \\
& & Aceh & 11 & 8,2 \\
3 & \multirow{4}{*}{ Behavior } & Jawa & 17 & 12,7 \\
& & Heavy drinkers & - & - \\
& & Gambler & - & - \\
& & Drug addicts & - & - \\
& & People who have HIV/AIDS & - & - \\
& & Homosexuals & - & - \\
\hline
\end{tabular}

The data in Table 5 above indicate that the whole subject still idolizes fellow Muslims as neighbors $(96.2 \%)$. From the ethnic aspect, the Malays are the most desirable to be neighbors $(68,4 \%)$. This phenomenon shows the ethnocentric importance of neighbors who come from the same religious and ethnic groups. This fact is a bad indication for multicultural education while pointing to the failure of education to form a plural character. In addition, this reality is a bad signal for political understanding in the form of strengthening religious and ethnic sentiments. When choosing regional legislative candidates or regents, for example, this phenomenon is certain to choose candidates based on religious and ethnic ties. The Butterfly effect of the election of the Governor of Jakarta in 2017 is very much felt in the election of the Governor of North Sumatra in 2018. The situation can be explained well. Facing the election in 2019, the terms such as Kafir (i.e. non-Moslem), pro-Asing (i.e. West), pro-Aseng (i.e. Chinese), $P K I$ (i.e. communist) and others are Anti-Incumbent sentiments.

There are no subjects chose neighbors who behaved as drunks, gamblers, drugs, people with HIV/AIDS or homosexuals. This indication is very paradoxical with its religiosity. The understanding of religion is not in line with social understanding. The description of negative 
behavior is the basis of rejecting his presence in the community. The dimension of democratic values directs society to accept individuals from various religions, ethnicities, and behaviors. This democratic value contains morality or ethics that is able to accept other people with various backgrounds. Such understanding can grow because the education factor teaches the value of universalism and humanism as the core of human rights. The tendency of ethnocentrism has an impact on the dimension of democratic value in the form of interpersonal trust as shown in figure 2 below.

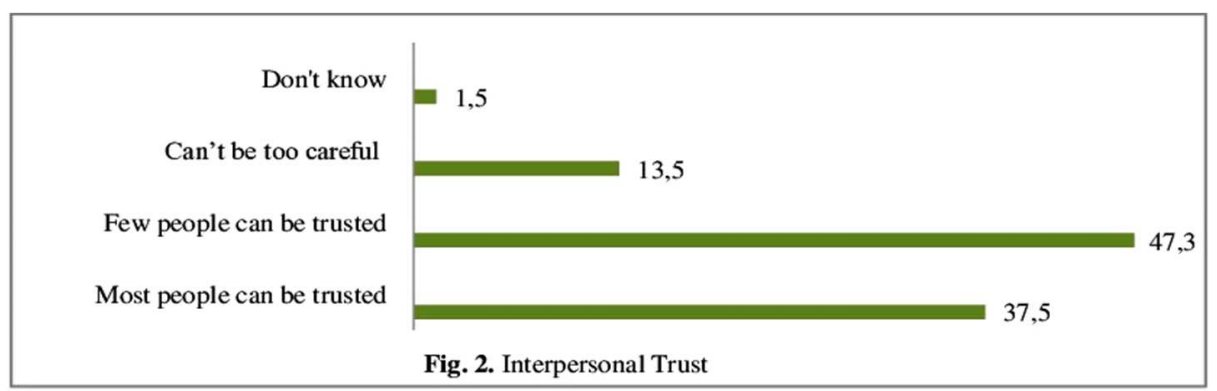

The data in figure 2 above shows only $37.5 \%$ said they believed in others. Meanwhile, $47.3 \%$ claimed that only a few people could be trusted, and $13.5 \%$ said that they were cautious enough to others. This indication shows that the subject becomes a very careful, unbelieving and always suspicious individual. This fact is a limiting factor for social interaction and communication. The political system with representatives requires interpersonal trust. If trust is low, the system of representation is very doubtful. Therefore, political culture has not grown well. Growing interpersonal trust is done through good education. However, this reality is still difficult for people who have low education. This situation has an impact on the meaning of politics as a means of segmented democracy based on religion and ethnicity. This fact is a bad signal for a multi-ethnic country like Indonesia, which is hoping for the coexistence of all differences in society. The education of citizens with national morality requires seriousness and urgency in the situation of decentralization. Local politics that develop must lead to national politics, namely to strengthen integration and not destabilize the life of the state.

The elections are considered not to correlate with the interests of the subject but only as ordinary political activity. The emergence of a statement that "whatever the president, governor, regent, mayor or parliament, our lives are determined by ourselves" is a reflection of pessimism. This statement may refer to past political experience, but actually, politics is not so, Politics is a state activity for a common goal. Therefore, mutual trust or commitment is a dimension of democratic value. This dimension becomes state capital in the scope of the high differences in social, cultural, ethnic and religious attributes. Interpersonal trust characters have an impact on pride in country. Figure 3 below describes pride in the country according to 133 subjects, namely: 


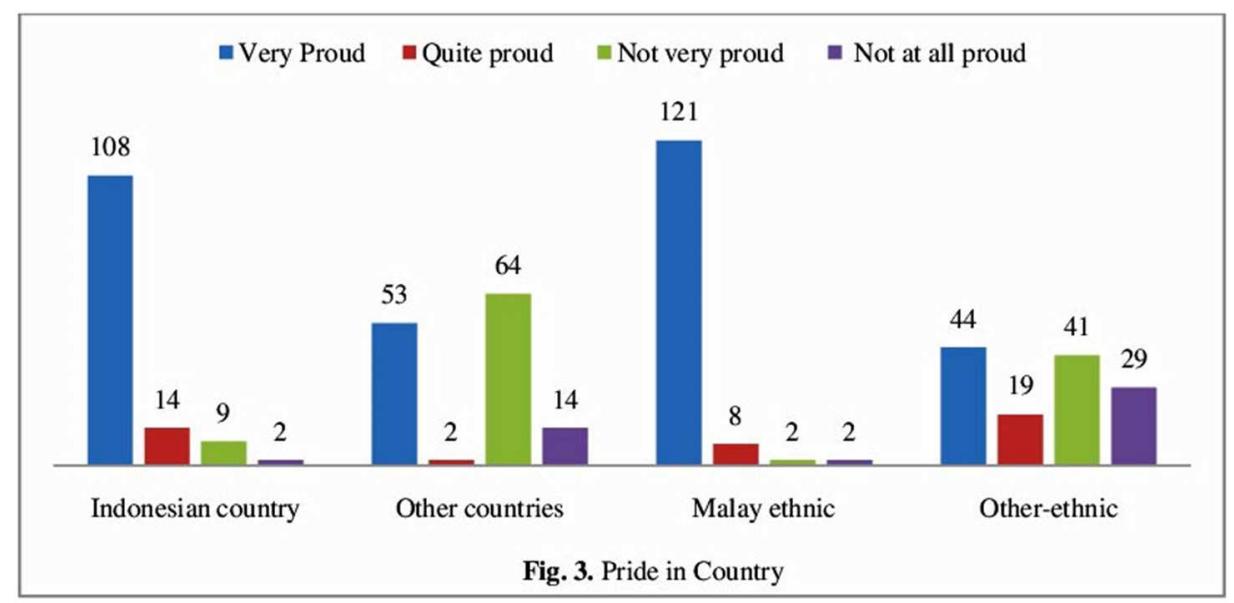

The data in figure 3 above shows the level of pride as Indonesia and ethnic Malays including other countries and ethnicities. In total $81,2 \%$ said they were proud of Indonesia, and $48.1 \%$ said they were not proud and respectful of other countries. Then, $90.9 \%$ expressed pride as ethnic Malays, and 33\% expressed pride in other ethnic groups. However, there are differences of opinion among other subjects. This data shows the pride of Malay as an ethnic in Indonesia. This phenomenon strengthens ethnocentrism while at the same time lacks interpersonal trust, which is an important element of the universal dimension of democratic values.

Democracy wants pride and honor as a nation and self. This dimension of democratic value is related to nationalism which contributes to the future of the nation. The more a person is proud to be a citizen, the more nationalist the individual is meant to be. The more nationalist is the higher his love for the nation. However, loyalty as ethnicity outweighs loyalty to the country. This reality is a bad indication for the growth of a democracy that moves partisan. This situation has an impact on the meaning and political participation that are often implied through political flow. Pride in the state contributes to state policies that are realized through political participation. This pride can grow if the community has a good education. In addition, the state guarantees economic, social, cultural and other welfare to its citizens as a factor in the development of pride in the country.

Nationalism, namely the love of the state, is channeled through political activities such as the election. Nationalism is awareness as a citizen. The citizens who are aware of having good political participation. Citizens like this understand that their political rights contribute to national development. Therefore, nationalists are certain to have an interest in politics. Figure 4 below shows the dimensions of democratic values in the form of attraction to some political activities in Indonesia, namely: 


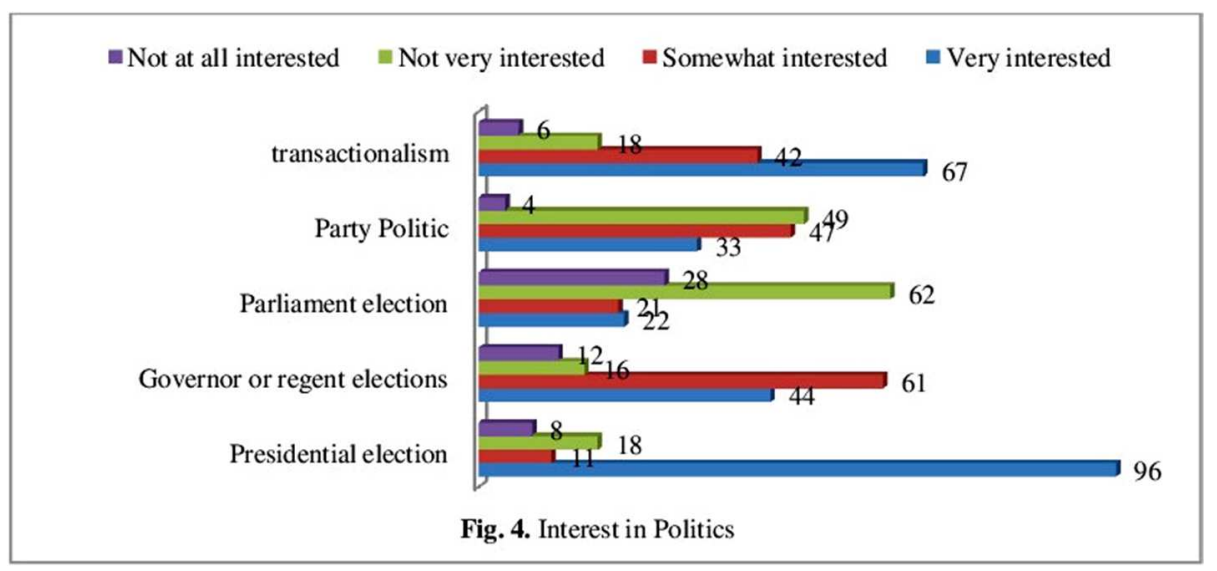

The data in figure 4 above indicate political interest in several respects: (i) there were $72.1 \%$ very interested in the presidential election, (ii) as many as $33 \%$ were very interested in the election of governors and regents, (iii) by $16.5 \%$ very interested in parliamentary elections, (iv) as much as $24.8 \%$ were very interested in political parties, and (v) as many as $50.3 \%$ were very interested in money politics. However, there were $46.6 \%$ who were very uninterested in parliamentary elections, $36.8 \%$ were very uninterested in political parties, and only $13.5 \%$ said they were not very interested in money politics. This data shows that the community was very enthusiastic about political activities, especially the presidential election but was not interested in parliamentary elections.

The interest in taking part in the presidential election was talked about based on information through television, print and online devices. Conversations and discussions install, religious activities, social gatherings, and activities have never been separated from the theme of the presidential election. This fact is due to the booming performance of Incumbents through the entire media. Meanwhile, parliamentary elections are the most unpopular political activity. This reality occurs because corruption cases ensnare parliamentarians or poor performance resulting in a crisis of trust. A bad portrait of parliament is presented by the media such as empty seats at the meeting, or the lack of product laws produced. In addition, interest in money politics in the form of money politics is still high. The character of money politics is inseparable from the low socio-economic conditions. It appears that the quality of human resources is still low due to the low quality of education and the different economic strata between the poor, middle and high classes.

Figure 5 below contains the dimensions of democratic values, namely subjective civic competence. This dimension of democratic value is a response to state policy. Citizens react to every state policy. Price increases, injustice, poverty, economic inequality, corruption, foreign debt, and others are central phenomena in this dimension. Against this phenomenon, citizens give reactions or attitudes that reflect subjective civic competence. The attitude of rejecting or accepting is a reflection of a critical, rational and objective society. This attitude is fundamental to the mechanism of check and balance. The subjective civic competence picture of 133 subjects is shown in figure 5 below. 


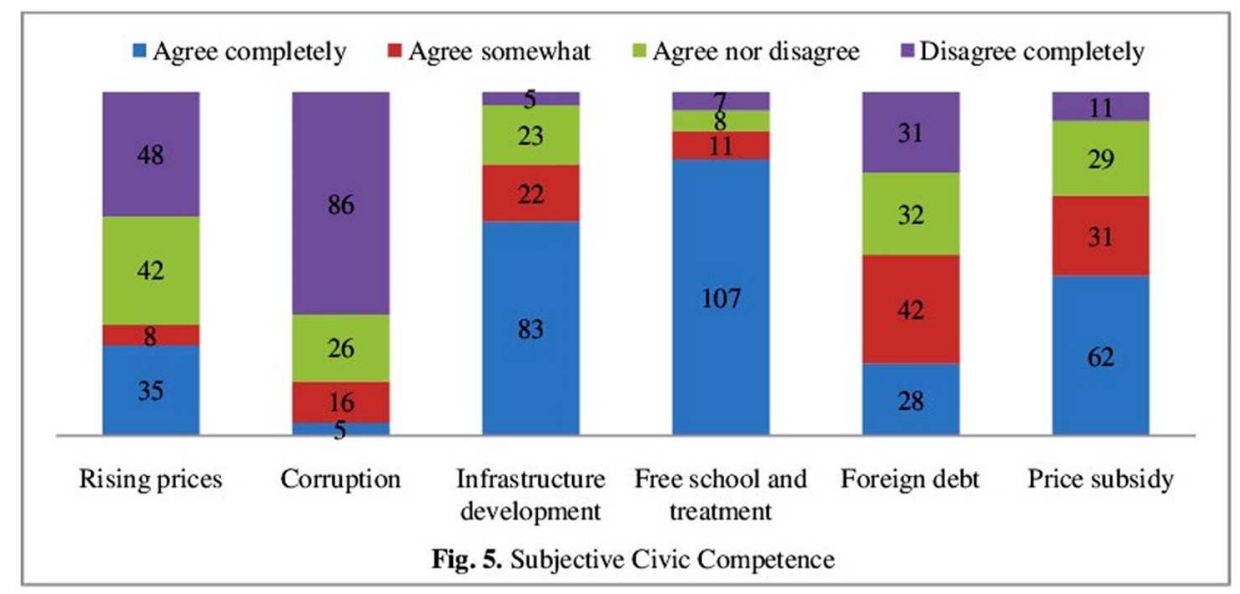

Figure 5 above shows subjective civic competence in the 6 dimensions of democratic value. Based on these data, there are important points on the response to disagreement, namely: (i) $36 \%$ price increase, (ii) $64.6 \%$ corruption behavior, and (iii) $23.3 \%$ foreign debt. In addition, the community strongly agreed on aspects: (i) corruption behavior $3.7 \%$, (ii) infrastructure development $62.4 \%$, (iii) free school and health $80.4 \%$, (iv) $21 \%$ public debt, and (v) subsidized prices of $46.6 \%$. This fact indicates that: (a) the impact of infrastructure development and health and school assistance is very much felt. One of the infrastructure felt by the community is the toll road that passes in Serdang Bedagei district, (b) the community rejects corruption because it becomes a disease for the life of the state. A large number of politicians entangled in corruption has an impact on the crisis of trust in state officials. This social reality shows that the community always follows the development of the state which refers to the love and pride of the state. This fact has a correlation with the political activities of the people facing the 2019 general election.

The dimension of democratic values namely subjective civic competence correlates with confidence in political institutions. The data in Table 6 below presents people's beliefs in political institutions. Apart from pointing to subjective civic competence, it is a perception of social-political institutions. This dimension presents an institution where people put comfort and how comfort can be created. This dimension presents an institution where people put comfort and how comfort can be created. The dimensions of comfort in socio-political institutions are an accumulation of the dimensions of previous democratic values, especially interpersonal trust, pride in country, and subjective civic competence. This dimension is a reference for systems, mechanisms, procedures and political substances that are adapted to the social system. It should be underlined that democracy can only grow well if there is comfort in social-political institutions as a driving force. Political parties are the accumulation of socialpolitical institutions where social activities move within them. Therefore, the confidence in social-political institutions has a correlation with the democratization process.

Tabel 6. Confidence in political institutions

\begin{tabular}{ccccc}
\hline Confidence in political institutions & \multicolumn{4}{c}{ Alternative answers } \\
\cline { 2 - 5 } & A great deal & Quite a lot & Not very Much & None at all \\
\hline Political party & 12 & 61 & 1 & 59 \\
Mosque & 102 & 21 & 3 & 9 \\
Education & 52 & 68 & 2 & 11
\end{tabular}




\begin{tabular}{ccccc}
\hline Confidence in political institutions & \multicolumn{4}{c}{ Alternative answers } \\
\cline { 2 - 5 } & A great deal & Quite a lot & Not very Much & None at all \\
\hline Law & 32 & 20 & 13 & 68 \\
Military & 41 & 52 & 3 & 30 \\
Pers & 38 & 27 & 14 & 54 \\
Police & 33 & 25 & 17 & 58 \\
State Civil Apparatus & 37 & 14 & 20 & 62 \\
Trading company & 20 & 18 & 68 & 27 \\
Parliament & 33 & 21 & 1 & 78 \\
Ethnic association & 72 & 21 & 6 & 34 \\
Religious association & 73 & 21 & 10 & 29 \\
\hline
\end{tabular}

The data in table 6 shows that public confidence in social-political institutions tends to be focused on religion (76.6\%), religious associations (54.8\%), ethnic associations $(54.1 \%)$ and education (39.0\%). The four social institutions have very intensive meeting members. Conversations and discussion of sociopolitical issues become material that is always discussed. In addition, educational institutions and religions are considered to be institutions that are directly related to changing politics. In addition, the data above presents that parliament $(58.6 \%)$, law $(51.1 \%)$, civil servants $(46.6 \%)$, political parties $(44.3 \%)$, police, $(43.6 \%)$, and the press $(40.6 \%)$ is the least trusted institution.

Corruption cases that ensnare civil servants, government employees, legal officials, state officials, businessmen, the police and others are the trigger for this bad sentiment towards these socio-political institutions. Legal injustice triggered a crisis of trust in legal officials. This phenomenon has an impact on the life of an unstable democracy. The socio-political institution that should have been the motor of the state organizer failed to carry out its functions. In situations of chaotic thinking and feeling the cause of the transition of political institutions that are considered credible. This transition leads to religious and ethnic institutions to discuss political reality. The influence of religious and ethnic figures is crucial. The communal worship activities that move from one city to another create confidence in this institution. This kind of social reality has an impact on evaluating political objects that give birth to political decisions. Political decisions are a consideration of political decisions in various public figures as shown in figure 6 below.

$=$ Religious figure $=$ Ethnic figure $=$ Party Politic figure $=$ Friend or families $=$ National figure

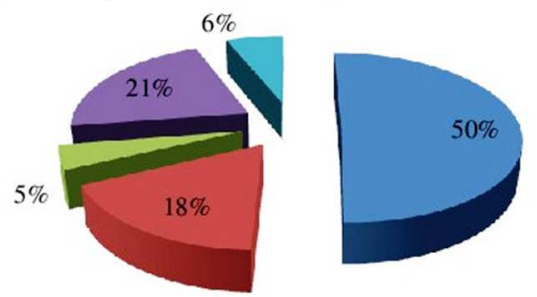

Fig. 6. Consideration of political decisions

The data in figure 6 above point to several important points about political decisions, namely: (i) $50 \%$ based on the influence of religious figures, (ii) $21 \%$ based on family figures, and (iii) $18 \%$ based on figures ethnicity. Meanwhile, national figures are considered $6 \%$ and 
political parties are only $5 \%$. Therefore, political decisions are still dominantly influenced by religious sentiments which permeate political life. This political culture characterized by religious division is still dominantly influencing political culture is facing general elections in 2019. Therefore, this study concludes that the political culture facing general elections in 2019 is still on the issue of religion and nationalism, namely nationalist-religious.

As mentioned at the beginning of this text, political culture refers to the behavior of individuals and groups, namely overall knowledge, emotional attitudes and moral-ethical judgments on political issues that affect life. Political behavior becomes a political phenomenon that occurs in the political system that comes from the culture of society. Political culture is part of the culture of society with more distinctive characteristics [20] and becomes a determining variable in political explanation [21]. This concept includes legitimacy, power regulation, government policy-making processes, political party activities, state apparatus behavior, community turmoil towards governing power or trust and tolerance[22]-[26]. Political culture is very dependent on education which contains the dimensions of knowledge, emotional attitudes, and evaluation of political objects. This study confirms that the low level of education influences the low political culture of citizens who are still fragmented on religious and ethnic issues. Religion and ethnicity are still political references because of the dominance of their figures in society.

Political culture is the core of fundamental beliefs that are widely shared and have political consequences. Explanation of political culture assumes that society has the same attitudes and values. However, the assumption of shared attitudes and values is more shared by ethnic groups than in the country's population. Therefore, ethnic and religious identification became the main alternative to the formation of national affiliations [27], [28]. This study states that ethnic and religious groups are still a political issue discussed. Some concepts like 'majority'; 'dominant'; 'interests of Umat', and others are phenomena that experience strengthening in society. This theme is a central issue in the political conversation with the public in facing elections in 2019. Political culture is still in the line of religion and is certainly guiding each of its adherents to religious character combined with nationalist character. Political culture is very dependent on culture, namely the characteristics and differences of ethnicity, cultural practices, religious, social, economic and educational practices [29]-[32].

In multi-ethnic societies, political culture is more determined by ethnicity [16]. Political culture shapes how individuals and society react politically [33]-[38]. Because it originates from shared attitudes and values, political culture becomes a distinctive orientation towards the political system with its various parts and roles within the political system [39]. Therefore, politics is a dynamic phenomenon in humans so that it becomes the basic unit of empirical study of political explanation [40]. Every individual in society is bound to his culture and thus influences his political culture. The formation of political culture is very much determined by the components of cognition (political knowledge), affection (political acceptance) and evaluation (political decisions). This study confirms that education is a major factor in the low fragmented political culture to religion and ethnicity. Political culture is polarized along religious and ethnic lines that continue to occur in elections in 2019.

The social reality of the community in this study tends to be communal based on religion, ethnicity, and culture. Each of these components demands loyalty from its members. This fact has an impact on the meaning of politics based on religion, ethnicity, and culture [41]. The inclusion of religion in political activities in Indonesia began in the era of President Habibie in 1999. When Susilo Bambang Yudhoyono became president, the Arab Spring flourished in Indonesia since 2011 [42]. This transnational activity was formed through regular media coverage of events in the Middle East. The Arab Spring phenomenon penetrated the Jakarta 
Election which caused a butterfly effect in various regions in Indonesia such as North Sumatra. This study states that political culture arises from decisions based on religious and ethnic considerations, which are largely influenced by the figures of the two social-political institutions. Therefore, the character needed in the election in 2019 tends to be religiousnationalist.

The impact of 21 st-century technological innovation has changed political life. Today's digital era is a differentiator of political campaigning in the pre-modern, modern and postmodern era [43]. The digital age expects the ability of smart individuals to use digital devices. Digital devices produce political culture and expand democratization efforts. Media in the digital era has changed the pattern of communication and the formulation of netizens political decisions regarding the public agenda and political preferences [44]. Digital devices form images to give access to power [45]. Digital media bridges the digital community in democratic activities and political participation of young people [46]. This fact has an impact on political culture in various countries including Indonesia. This study confirms that digital devices have not been fully utilized but are still limited to communication and entertainment. Digital political culture has not been formed so that the dominance of themes and religious figures is still a political reference to the face of the election in 2019.

Socio-political institutions such as political parties, religious, ethnic, parliamentary, military, police, educational associations, laws are very important in creating a political culture. As the main motor of politics, political parties are institutions that are most responsible for educating cadres and the community. Political parties become tools to realize the ideals of nation and state through the creation of quality democracy [47]. However, contemporary political activities in Indonesia are very different. Political parties fail to carry out political education or create a multidisciplinary mechanism in regional head elections. Political parties fail to carry out their functions as checks and balances. DPR and DPRD institutions fail to create and disseminate democratization [48], [49]. The crisis of trust in political parties has an impact on the transition to religious institutions. Ironically, political parties lose their idealism. Political parties are trapped in the politicization of religion through various sentiments. While other institutions failed to bring public trust. Distrust of public officials is increasingly felt.

The education in the digital era became significant. Education directs individuals to a healthy and quality political culture. Education in the digital era is a determinant of digital political culture, namely "political information literacy". However, this expectation is still utopian because of the failure of social-political institutions, political parties and the educational realities of the Indonesian people. This fact has an impact on the loss of political references. The media and unreliable figures create a healthy and quality political culture. The impact is that every information is consumed without filters and is used as the truth of political information.

Based on the description above, the findings of this study are that education has an impact on the low political culture that is still tied to the religious line. Education does not produce a digital political culture because of limited education. Knowledge, feelings, and evaluation of political objects are still focused on religious sentiments. The findings on the 7 dimensions of democratic values direct the novelty of this study that parochial political culture still dominates in the elections in 2019. This parochial political culture guides the public to the selection of religious-nationalist characters. Finally, the contribution of this study confirms that the Indonesian political culture still reflects parochial namely the low participation and political awareness of citizens as noted by Almonds and Verba. 


\section{Conclusions}

The digital political culture includes cognition (political knowledge), affection (political acceptance) and evaluation (political decisions) of political objects. This digital political culture is formed because of good and quality education and digital political knowledge. The ability to manage digital political information guides the community to the creation of voting behaviors based on rational considerations. Digital political culture is grown through information updates through print, online, television and social network application media. However, a quality digital political culture is not formed at all because of the low level of education and the failure of social-political institutions.

This study summarizes the three main points, namely: (i) the low level of education contributes to the low 7 dimensions of democratic values which include achievement motivation, ethnocentrism, interpersonal trust, pride in country, subjective political competence, interest in politics and belief in political institutions, (ii) digital political culture, namely knowledge, affection and evaluation of political objects, the combination of levels of education and digital knowledge is still fragmented on religious lines, (iii) the typology of digital political culture is parochial, namely political participation and awareness, and (iv) the digital political culture is trapped in religious sentiments that guide voting behavior to nationalist-religious characters. As a recommendation, this study suggests that research on political culture in multiethnic societies includes more complex dimensions of democratic values in accordance with the character of the people.

\section{Acknowledgments}

Special appreciation and thanks to the director of the SI-NGO who has funded this research. The same was conveyed to all parties who had helped during the process and completion of this research.

\section{References}

[1] G. A. Almond, The Civic Culture: Political Attitudes and Democracy in Five Nations. Princeton, NJ: Princeton University Press., 1963.

[2] M. Weber, The Protestant Ethic and the Spirit of Capitalism. London and New York: Routledge., 1992.

[3] S. Whitefield, "Political Culture versus Rational Choice: Explaining Responses to Transition in the Czech Republic and Slovakia," Br. J. Polit. Sci., vol. 29, no. 1, pp. 129-154, 1999.

[4] M. D. Wicaksono, "Profesor Akhmaloka: Rata-rata Masyarakat RI Tidak Lulus SMP.," Profesor Akhmaloka: Rata-rata Masyarakat RI Tidak Lulus SMP., 2016. [Online]. Available: https://finance.detik.com/. [Accessed: 16-Dec-2018].

[5] D. Y. Jin, Digital Platforms, Imperialism, and Political Culture. New York and London: Routledge, 2015.

[6] E. L. Damanik, "WhatsApp dan Pemilih Pemula di Kota Medan: Partisipasi Politik Era Demokrasi Digital pada Pemilihan Gubernur Provinsi Sumatera Utara 2018.," J. Soc. Media, vol. 2, no. 2, pp. 81-108.

[7] M. Moura, "WhatsApp in Brazil: mobilizing voters through door-to-door and personal messages.," Internet Policy Rev., vol. 6, no. 4, pp. 1-18, 2017.

[8] B. Davis, "Hashtag Politics: the Polyphonic Revolution \#Twitter," Pepperdine J. Commun. Research, vol. 1, no. 4, pp. 16-22, 2013.

[9] S. Prokhorov, "Social Media and Democracy: Facebook as a Tool for the Establishment of 
Democracy in Egypt.," Malmo University., 2012.

[10] M. I. Lazar, "Reinforcing Democracy through Internet and Social Networks Participation: Votes, Voters and Elected Behavioral Outcomes in Romanian Presidential Elections (2014)," RSP, no. 46, pp. 63-72, 2015.

[11] S. Jaffares, Interpreting hashtag politics: policy ideas in an era of Social Media. UK: Palgrave MacMillan, 2014.

[12] E. L. Damanik, "Hashtag \#2019GantiPresiden: Sentiment Anti-Petahana dan Orientasi Politik Pemilih Pemula Menghadapi Pilpres 2019 di Pematangsiantar," J. Ilmu Pemerintah. dan Sos. Polit. UMA (Journal Gov. Polit. Soc. UMA), vol. 6, no. 2, pp. 166-176.

[13] A. Weber, I. Garimella, V. R.K \& Teka, "Political hashtag trends," in European Conference on Information Retrieval, 2013, pp. 857-860.

[14] S. Jeffares, Interpreting Hashtag Politics: Policy Ideas in an Era of Social Media. United Kingdom: Palgrave Macmillan, 2014.

[15] K. Marijan, Sistem Politik Indonesia: Konsolidasi Demokrasi Pasca Orde Baru. Jakarta: Kencana, 2011.

[16] B. D. Silver, "Measuring Political Culture in Multi-Ethnic Societies: Reaggregating the World Values Survey.," Comp. Polit. Stud., 2000.

[17] R. Inglehart, Modernization and postmodernization: cultural, economic, and political change in 43 societies. Princeton, NJ: Princeton University Press., 1997.

[18] Kantor, Profil Desa Sialang Buah, Kecamatan Teluk Mengukudu, Kabupaten Serdang Bedagei. Sialang Buah. Sei Rampah, 2018.

[19] KPU-RI, "Daftar Pemilih Tetap di Desa Sialang Buah, Kecamatan Teluk Mengkudu, Kabupaten Serdang Bedagei, provinsi Sumatera Utara.," Daftar Pemilih Tetap di Desa Sialang Buah, 2018. [Online]. Available: www.kpu.id. [Accessed: 16-Dec-2018].

[20] H. Suryo, "Budaya Politik Negara Maju dan Negara Berkembang: Suatu Perbandingan," J. Transform., vol. 27, no. 1, pp. 31-39, 2017.

[21] E. W. Lehman, "On the Concept of Political Culture: A Theoretical Reassessment.," Soc. Forces, vol. 50, no. 3, pp. 361-370, 1972.

[22] S. Chilton, "Defining Political Culture," West. Polit. Q., vol. 41, no. 3, pp. 419-445, 1998.

[23] R. P. Formisano, "The Concept of Political Culture.," J. Interdiscip. Hist., vol. 31, no. 3, pp. 393426, 2001.

[24] D. J. Elkins, "A Cause in Search of Its Effect, or What Does Political Culture Explain?," Comp. Polit., vol. 11, no. 2, pp. 127-145, 1979.

[25] C. G. Rivero, "Political culture and democracy: The South African case," Politikon, vol. 29, no. 2, pp. 161-181, 2002.

[26] S. K. Paul, "Political Culture in Indian Society," Int. J. Emerg. Trends Sci. Technol., vol. 5, no. 1, pp. 6498-6504, 2018.

[27] C. Geertz., "The integrative revolution: primordial sentiments and civil politics in the new states.," in The interpretation of cultures, C. Geertz, Ed. New York: Basic Books., 1973, pp. 255-310.

[28] T. R. Gurr, Minorities at risk: a global view of ethnopolitical conflicts. Washington, D.C.: Institute of Peace Press, 1993.

[29] G. A. Almond, The Politics of the Developing Areas. New Jersey: Princeton., 1970.

[30] R. A. Dahl, Modern Political Analysis. New Delhi: Prentice-Hall of India Private Limited., 1974.

[31] M. Budiardjo, Dasar-Dasar Ilmu Politik. Jakarta: Gramedia Pustaka Utama, 1982.

[32] R. Surbakti, Memahami Ilmu Politik. Jakarta: Gramedia Widiasarana Indonesia, 2010.

[33] D. L. Paletz, "Political Culture and Political Communication.," Barcelona, 92, 1994.

[34] J. S. Duffield., "Political Culture and State Behavior: Why Germany Confounds Neorealism.," Int. Organ., vol. 53, no. 4, pp. 765-803, 1999.

[35] F. C. da Silva, Political Culture. The International Encyclopedia of Political Communication. John Wiley \& Sons Inc, 2015.

[36] G. Helgesen, "Politics, Culture, and Self East Asian and North European Attitudes.," Copenhagen S, Denmark, 40, 2006.

[37] S. Feldman, "The Political Culture of Ambivalence: Ideological Responses to the Welfare State.," 
Am. J. Pol. Sci., vol. 36, no. 1, pp. 268-307, 1992

[38] W. A. Gamson, "The Political Culture of Social Welfare Policy.," Michigan, 242, 1981.

[39] G. A. Almond, "The Study of Political Culture.," in Culture and Politics., L. C. Crothers, Ed. New York: Palgrave MacMillan, 2000.

[40] A. B. Nambo, "Memahami Beberapa Konsep Politik: Suatu Telaah dari Sistem Politik," J. Mimb., vol. XXI, no. 2, pp. 262-285, 2005.

[41] E. L. Damanik, Politik Lokal: Dinamika Etnisitas pada era Desentralisasi di Sumatera Utara. Medan: Simetri Institute.

[42] A. R. M. Umar, "Media Sosial dan Revolusi Politik: Memahami Kembali Fenomena 'Arab Spring' Dalam Perspektif Ruang Publik Transnasional.," J. Ilmu Sos. dan Ilmu Polit., vol. 18, no. 2, pp. $114-129,2014$

[43] P. N. Howard, "Digitizing the Social Contract: Producing American Political Culture in the Age of New Media.," Commun. Rev., vol. 6, pp. 213-245, 2003.

[44] A. Esarey, "Digital Communication and Political Change in China.," Int. J. Commun., vol. 5, pp. 298-319, 2011

[45] M. Stocchetti, "Images and Power in the Digital Age: The political role of digital visuality.," 1, 2014.

[46] P. Collin, "Young Citizens and Political Participation in a Digital Society: Addressing the Democratic Disconnect," Commun. Polit. Cult., vol. 48, no. 1, pp. 85-86, 2015.

[47] Y. D. Saputro, "Peran Partai Politik Dalam Pendidikan Politik Generasi Muda dan Implikasinya Terhadap Ketahanan Politik Wilayah: Studi di DPD II Partai Golongan Karya Kota Malang Jawa Timur Tahun 2009-2014.," J. Ketahanan Nas., vol. XXI, no. 1, pp. 34-42, 2015.

[48] R. D. Adiputri., "Political Culture in the Indonesian Parliament: Analyzing Parliamentary Debates on the Regional Parliaments 1999-2009.," 2015.

[49] S. Eklöf, Power and Political Culture in Suharto's Indonesia: The Indonesian Democratic Party (PDI) and Decline of the New Order (1986-98). Copenhagen S, Denmark: NIAS Press, 2003. 